\title{
NATURAL HISTORY NOTE \\ Confirmation of the presence of Plecotus macrobullaris Kuzyakin, 1965 in Liguria (North-West Italy) (Chiroptera: Vespertilionidae)
}

\author{
Mara Calvini ${ }^{1,}{ }^{*}$, Roberto Toffoli ${ }^{1}$
}

\author{
${ }^{1}$ Chirosphera Associazione per lo \\ studio e la tutela dei Chirotteri e \\ l'ambiente. Via Tetti Barbiere 11, \\ 10128 Santena TO, Italy \\ *Corresponding author: \\ mara.calvini@gmail.com \\ DOI: https://doi.org/10.14709/ \\ BarbJ.10.1.2017.01 \\ Keywords: Italy, Liguria, \\ mitochondrial DNA, Plecotus \\ macrobullaris, alpine long-eared \\ bat, mountain long-eared bat. \\ received: January, 23th 2017 \\ accepted: March, 18th 2017
}

\begin{abstract}
We present the second confirmed record of the Alpine Long-eared Bat, Plecotus macrobullaris in Liguria, province of Imperia (NW Italy) on the basis of a male Plecotus found dead in Sanremo. The specific attribution of the specimen was based on the morphological characters and subsequently confirmed through genetic analysis of the mitochondrial COI DNA barcoding sequence. This record suggests the tendency of the species to occupy areas at lower altitudes in coastal areas close to the mountains, as well as confirms the presence of the species in this part of the region after 45 years. This new report extends the distribution range of $P$. macrobullaris further eastward than it was previously known. In order to know the real distribution of this species and acquire enough data to assess its conservation status, it would be essential to conduct more research targeting this species in future projects.
\end{abstract}

Plecotus macrobullaris Kuzyakin 1965 was considered as a subspecies of Plecotus auritus (Kuzyakin 1965) until species rank was confirmed by Kiefer \& Veith (2001) and Spitzenberger et al. (2002). Plecotus species are overall very similar to each other, which makes their field identification extremely complex and sometimes impossible. In particular, their biometric characteristics greatly overlap between species, and the lack of easily recognizable morphological characters (Ashrafi et al. 2010, Tvrtkovic et al. 2005), strongly suggests that genetic analyses need to be performed in order to correctly identify the various species, especially outside their common distribution range (Alberdi et al. 2016). The identification uncertainty is the basis for the scarcity of circumstantiated records of Plecotus macrobullaris, and as a result, its conservation status is Data Deficient (DD) in the Italian Red List of Mammals (Rondinini et al. 2013).

Plecotus macrobullaris is characterized by a mountainous distribution range with stable populations in the Pyrenees, Alps, Dinaric Alps, Greece, Crete, Corsica, Turkey, Middle East, and Caucasus (Dietz \& Kiefer 2014). In Italy, P. macrobullaris is rarely reported in the mountain areas of the Northern Regions, in particular the species is reported in Piemonte (Toffoli et al. 2016, Trizio et al. 2003), Valle d'Aosta (Debernardi\& Patriarca 2008), Lombardia (Trizio et al. 2005), Veneto (Ferretto \& Pereswiet-Soltan 2016, Kiefer \& Veith 2001), Trentino (Chirichella et al. 2003), and in Friuli Venezia-Giulia (Lapini et al. 2013, Spitzenberger et al. 2006). In Liguria, the species is reported on the basis of a single specimen of unknown sex preserved in the Natural History Museum of Wien (NMW 150005), collected at Sanremo (Imperia) on 7th July 1972 (Spitzenberger et al. 2002).
Here we present the second confirmed recording of Plecotus macrobullaris in Liguria after 45 years and some elements to better define the species' distribution range in the Italian Alps.

We analyzed an adult male Plecotus, in accordance with epiphysis ossification of the phalanges (Dietz \& von Helversen 2004), found dead near Sanremo (Imperia, NW Italy; $43^{\circ} 50^{\prime} 12^{\prime \prime} \mathrm{N} 7^{\circ} 45^{\prime} 22^{\prime \prime} \mathrm{E}$ ) on 28th August 2010 at a very low altitude (about $30 \mathrm{~m}$ asl) (Fig. 1). The locality is characterized by a vegetation mosaic with Mediterranean scrub forest alternating with Olive groves, small forest patches of Quercus pubescens, and rocky outcrops near isolated houses.

The specimen was measured with a digital caliper (accuracy $0.01 \mathrm{~mm}$, see Table 1 ) and subsequently frozen. A tissue sample preserved in Ethanol 95\% was later examined (September 2016) by the Dept. of Mammalogy and Ornithology at the Natural History Museum of Geneva (Switzerland), where the standardized COI barcode sequence was amplified using the primers UTyr and C1L705, following the method suggested by Hassanin et al. (2009). The generated sequence was compared to other Plecotus DNA barcoding reference sequences retrieved in GenBank using the BLAST algorithm.

The specimen is now preserved in the Mammalogy collection of the Museo Civico di Storia Naturale of Carmagnola (TO, Piedmont, Italy) with the acronym and catalogue number: MCCI 1043. 


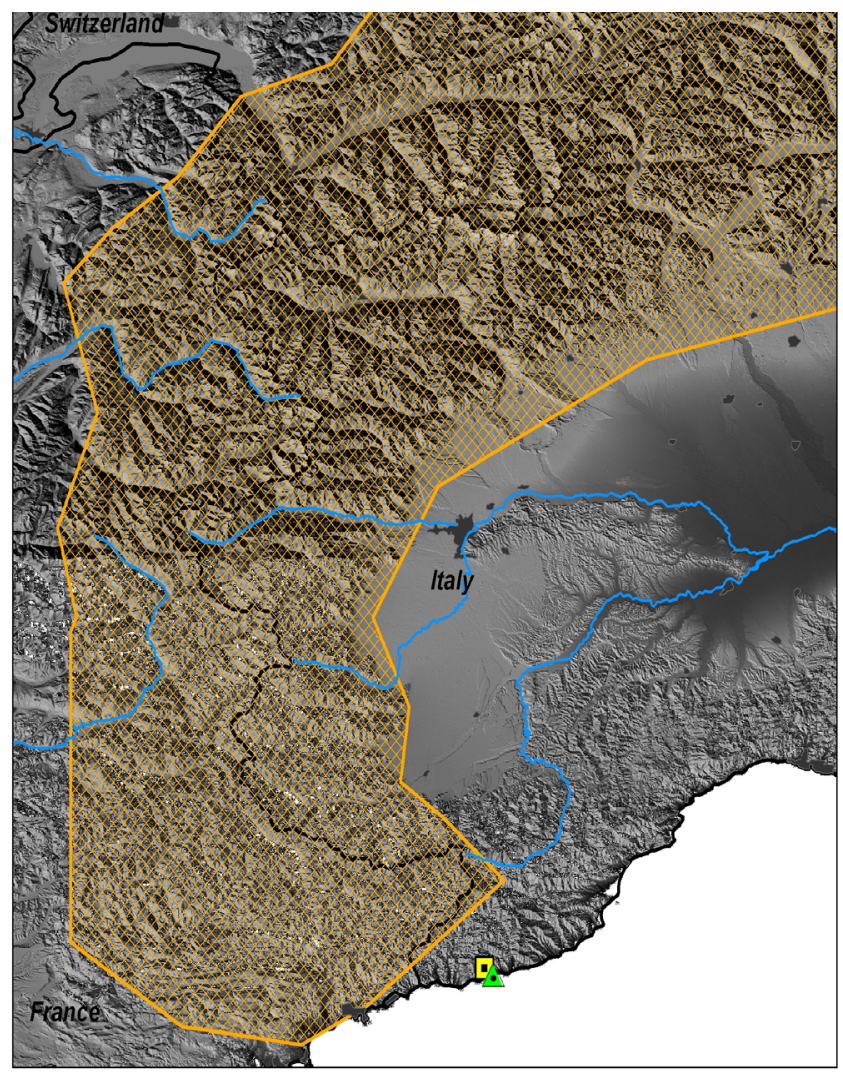

- Record in Spitzenberger et al., 2002

Record this study

Plecotus macrobullaris (distribution range IUCN) country

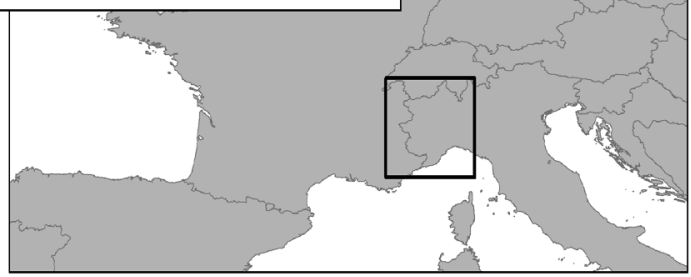

Fig. 1 - Record of Plecotus macrobullaris in Liguria and the distribution area in the Western Alps according to IUCN (2017).

The morphology and measurements of the specimen from Sanremo greatly recall those of the Plecotus macrobullaris described in the literature. In particular, the dorsal fur is constituted by tricolor hairs with a black base, light grey in the mid-part, and dark grey at the top, while the ventral side is light grey. The fur color agrees with that described by Kiefer \& Veith (2001) for Plecotus macrobullaris, even if other authors have reported different color patterns for the species, including individuals with greyish or yellowish underparts (Spitzenberger et al. 2002, Garin et al. 2003, Tvrtkovi et al. 2005, Spitzenberger et al. 2006).
A hard triangular pad extends from the lower lip towards the chin. The triangular chin pad is considered a good diagnostic characteristic of Plecotus macrobullaris by different authors (Dietz \& Kiefer 2014, Spitzenberger et al. 2006, Tvrtkovi et al. 2005, Spitzenberger et al. 2002), although they do not ensure a $100 \%$ correct identification like DNA analysis. Unfortunately, the shape of the penis was not clearly detected, due to the degeneration of the soft tissues, which occurs almost immediately after the death, particularly in the genital region. Genetic analyses conducted on the tissue sample returned the $730 \mathrm{bp}$ long nucleotide sequence deposited on GenBank with the number KY364276. This sequence was $100 \%$ similar to other reference $\mathrm{COI}$ sequences of $P$. macrobullaris of Western lineages (Alberdi et al. 2015b), from Spain, France, and Italy, as previously suggested by the morphological and biometrical observations. As previously reported by Galimberti et al. (2012), P. macrobullaris can be univocally distinguished from other European congenerics by using the mitochondrial COI.

This new specimen, found in the same locality of the only other $P$. macrobullaris from Liguria, confirms the presence of the species in this part of the region after 45 years (Spitzenberger et al. 2002), even sporadically. This species is probably more common than is thought based on the known records. Additionally, our results seem to indicate that the distribution range extends further eastward than was previously known, almost in continuity with the populations of the Roja valley, Alpes Maritimes (France), and extend very close to the Italian border (Drousie et al. 2016). The Sanremo records also confirm the tendency of the species to occupy areas at lower altitudes, as has been previously recorded in Mediterranean France and in other parts of the Alps (Drousie et al. 2016, Alberdi et al. 2013). In particular, Plecotus macrobullaris tends to occupy the mountain reliefs with steep slopes and rocky outcrops, such as those observed in Western Liguria, not only in the Sanremo area (Alberdi et al. 2014). The place where the specimen has been found, even if it is characterized by habitats not perfectly suitable for the species, is not that far from the ecological optimum areas of the Ligurian and Maritimes Alps (Alberdi et al. 2014). This fact combined with the documented daily movements of 5-6 km with an additional altitudinal shift of several hundred meters (Alberdi et al. 2014), suggests the possibility that some individuals regularly occur in the coastal areas close to the mountains. Finally, the date of the specimen recovery could also indicate post-breeding dispersal movements, even if they have never been documented for the species.

On the other hand, our analysis confirms the validity of the morphological characteristics suggested for the species, particularly the triangular pad extending towards the chin at the lower lip. To know the real distribution range of this

Table 1 - Biometric measures $(\mathrm{mm})$ detected on the specimen of Plecotus macrobullaris and typical ranges of the species according to Dietz \& Kiefer (2014) in parentheses.

\begin{tabular}{cccccccccc}
\hline Data & Locality & Province & Sex & Forearm & Digit 3 & Digit 4 & Foot & Tragus \\
\hline \multirow{2}{*}{ 28th August 2010 } & \multirow{2}{*}{ Sanremo } & Imperia & \multirow{2}{*}{$*$} & 40,38 & 67,10 & 49,50 & 8,44 & 16,52 \\
& & & & $(37,3-46,0)$ & $(63,0-72,0)$ & $(49,0-58,0)$ & & $(15,5-19,0)$
\end{tabular}


elusive species and acquire the needed data to assess its conservation status, we strongly suggest targeted research in Western Liguria and in other areas suitable for Plecotus macrobullaris.

\section{ACKNOWLEDGEMENTS}

We are grateful to T. Andriollo of the Natural History Museum in Geneva for supporting and cooperation with genetic analysis and thank to A. Galimberti and M. Pavia for the revision of the text

\section{REFERENCES}

ALBERDI, A., GARIN, I., AIZPURUA, O. \& AIHARTZA, J. (2013). Review on the geographic and elevational distribution of the mountain long-eared bat Plecotus macrobullaris, completed by utilising a specific mistnetting technique. Acta Chiropterologica 15(2): 451-461. http://dx.doi.org/10.3161/150811013X679071

ALBERDI, A., AIZPURUA, O., AIHARTZA, J. \& GARIN, I. (2014). Unveiling the factors shaping the distribution of widely distributed alpine vertebrates, using multi scale ecological niche modelling of the bat Plecotus macrobullaris. BioMed Central Ltd. Frontiers in Zoology 11: 77. http://dx.doi.org/10.1186/s12983-014-0077-6

ALBERDI A., AIHARTZA J., AIZPURUA O., SALSAMENDI E., BRIGHAM M. \& GARIN I. (2015a). Living above the treeline: roosting ecology of the alpine bat Plecotus macrobullaris. European Journal of Wildlife Research 61: 17-25. http://dx.doi.org/10.1007/s10344-014-0862-8

ALBERDI, A., GILBERT, M.T.P., RAZGOUR, O., AIZPURUA, O., AIHARTZA, J. \& GARIN, I. (2015b). Contrasting population-level responses to Pleistocene climatic oscillations in an alpine bat revealed by complete mitochondrial genomes and evolutionary history inference. Journal of Biogeography 42(9): 1689-1700. http://dx.doi.org/10.1111/jbi.12535

ALBERDI, A., AIZPURUA, O., AIHARTZA, J. \& GARIN, I. (2016). Ecology, biogeography and evolutionary history of the alpine long-eared bat Plecotus macrobullaris. Galemys 28. http://dx.doi.org/10.7325/Galemys.2016. A1

ASHRAFI, S., BONTADINA, F., KIEFER, A., PAVLINIC, I. \& ARLETTAZ, R. (2010). Multiple morphological characters needed for field identification of cryptic long-eared bat species around the Swiss Alps. Journal of Zoology 281: 241-248. http://dx.doi.org/10.1111/j.14697998.2010.00697.x

CHIRICHELLA, R., MATTIROLI, S., NODARI, M., PREATONI, D., WAUTERS, L., TOSI, G. \& MARTINOLI, A. (2003). The Adamello-Brenta Natural Park bat community (Mammalia, Chiroptera): distribution and population status. Hystrix 14(1-2): 29-45. http://dx.doi.org/10.4404/ hystrix-14.1-2-4314
DEBERNARDI, P. \& PATRIARCA, E. (2008). Prima segnalazione di Myotis bechsteinii, Myotis daubentonii, Myotis nattereri, Nyctalus leisleri, Pipistrellus pygmaeus, Plecotus macrobullaris e Tadarida teniotis in Valle d'Aosta. Aggiornamento dell'inventario dei chirotteri noti per la regione. Revue Valdôtaine d'Histoire Naturelle 62: 5-27.

DIETZ, C., \& KIEFER, A. (2014) .Pipistrelli d'Europa. ed.: Ricca Editore, Roma, Italy 400 pp.

DIETZ, C., \& VON HELVERSEN, O. (2004). Illustrated identification key to the bats of Europe. Electronic publication, version1.0, $72 \mathrm{pp}$.

DROUSIE, M., CORAIL, M. \& COSSON, E. (2016). L'oreillard montagnard Plecotus macrobullaris. In: (LPO, PACA, GECEM 6 GCP. Les Mammifères de Provence-Cote d'Azur). Biotope Mèze: 112-113.

FERRETTO, M. \& PERESWIET-SOLTAN, A. (2016). Presenza di orecchione alpino, Plecotus macrobullaris, in provincia di Vicenza (Chiroptera: Vespertilionidae). In: (Bonato L., Trabucco R., Bon M. eds.). Atti $7^{\circ}$ Convegno Faunisti Veneti. Bollettino del Museo civico di storia naturale di Venezia., suppl. vol. 66, 292 pp.

GALIMBERTI, A., SPADA, M., RUSSO, D., MUCEDDA, M., AGNELLI, P., CROTTINI, A., FERRI, E., MARTINOLI, A. \& CASIRAGHI, M. (2012). Integrated operational taxonomic units (IOTUs) in echolocating bats: a bridge between molecular and traditional taxonomy. PloS one 7(6): e40122. https://doi.org/10.1371/journal. pone.0040122

GARIN, I., GARCÍA-MUDARRA, J.L., AIHARTZA, J.R., GOITI, U. \& JUSTE, J. (2003). Presence of Plecotus macrobullaris (Chiroptera: Vespertilionidae) in the Pyrenees. Acta Chiropterologica 5 (2): 243-250. http:// dx.doi.org/10.3161/001.005.0207

HASSANIN, A., ROPIQUET, A., COULOUX, A. \& CRUAUD, C. (2009). Evolution of the mitochondrial genome in mammals living at high altitude: new insights from a study of the tribe Caprini Bovidae, Antilopinae. J. Mol. Evol. 68: 293-310. http://dx.doi.org/10.1007/s00239009-9208-7

IUCN 2017 Plecotus macrobullaris (February 20). The IUCN Red List of Threatened Species . Version 2014.1.

KIEFER, A.\& VEITH, M. (2001). A new species of long-eared bat from Europe (Chiroptera: Vespertilionidae). Myotis 39: 5-16.

KUZYAKIN, A. (1965). Otrjad Rukokrylyje. Ordo Chiroptera: 79-116. In: Bobrinskij N., Kuznetsov B. \& Kuzjakin A.: Opredelitel mljekopitayushtshikh SSSR. Isd. Prosveshtshenije. Moskva. 
LAPINI, L., DORIGO, L., GLEREAN, P. \& GIOVANNELLI, M.M. (2013). Status di alcune specie protette dalla Direttiva Habitat 92/43/CEE nel Friuli Venezia Giulia (Invertebrati, Anfibi, Rettili, Mammiferi). Gortania (Botanica, Zoologia) 35: 61-139.

RONDININI, C., BATTISTONI, A., PERONACE, V. \& TEOFILI, C. (2013). Lista Rossa IUCN dei Vertebrati Italiani. Comitato Italiano IUCN e Ministero dell'Ambiente e della Tutela del Territorio e del Mare, Roma, Italy, 54 pp.

SPITZENBERGER, F., HARING, E. \& TVRTKOVI, N. (2002). Plecotus microdontus (Mammalia, Vespertilionidae), a new bat species from Austria. Natura Croatica 11(1): 1-18.

SPITZENBERGER, F., STRELKOV, P., WINKLER, H. \& HARING, E. (2006). A preliminary revision of the genus Plecotus (Chiroptera, Vespertilionidae) based on genetic and morphological results. Zoologica Scripta 35: 187-230. http://dx.doi.org/10.1111/j.1463-6409.2006.00224.x
TVRTKOVI, N., PAVLINI, I. \& HARING, E. (2005). Four species of long-eared bats (Plecotus, Geoffroy, 1818; Mammalia, Vespertilionidae) in Croatia: field identification and distribution. Folia Zool. 54(1-2): 75-88.

TOFFOLI, R., CULASSO, P., LOCATELLI, A.G. \& GIRAUDO, L. (2016). Bats of Alpi Marittime Nature Park (North West Italy) and Site of Community Importance IT1160056: distribution and status. Natural History Sciences 3(1): 3-13. http://dx.doi.org/10.4081/nhs.2016.254

TRIZIO, I., PATRIARCA, E., DEBERNARDI, P., PREATONI, D., TOSI, G. \& MARTINOLI, A. (2003). The Alpine LongEared Bat (Plecotus alpinus Kiefer and Veith, 2001) is present also in Piedmont Region: first record revealed by DNA analysis. Hystrix 14(1-2): 113-115. http://dx.doi. org/10.4404/hystrix-14.1-2-4321

TRIZIO, I., PREATONI, D., CHIRICHELLA, R., MATTIROLI, S., NODARI, M., CREA, S., TOSI, G. \& MARTINOLI, A. (2005). First record of the alpine long-eared bat (Plecotus macrobullaris Kuzjakin, 1965) in Lombardy (Northern Italy) revealed by DNA analysis. Natura Bresciana, Ann. Mus. Civ. Sc. Nat. Bresciana 34: 171-175. 